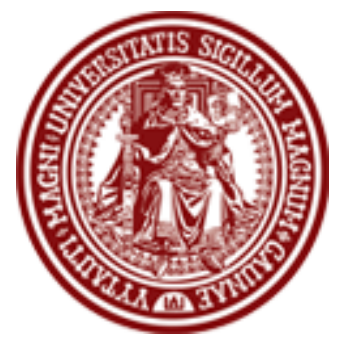

BALTIC JOURNAL OF LAW \& POLITICS

VOLUME 4, NUMBER 1 (2011)

ISSN 2029-0454

http://www.versita.com/bjlp

Cit.: Baltic Journal of Law \& Politics 4:1 (2011): 169-201

DOI: $10.2478 / \mathrm{v} 10076-011-0008-1$

\title{
LIMITED ENGAGEMENT OF THE CHILD IN POLITICAL ISSUES: THE RIGHT WHICH EVOLVED AT THE UNIVERSAL LEVEL BUT IS STILL UNACKNOWLEDGED BY MOST REGIONAL INSTRUMENTS
}

\author{
Mariya Riekkinen \\ Ph.D. Candidate; Researcher \\ The Åbo Akademi University, Faculty of Law (Finland) \\ Contact information \\ Address: Gezeliusgatan, 2, 20500 Abo/Turku, Finland \\ Phone: +358-2-2154692 \\ E-mail address: mpimanov@abo.fi
}

Received: February 29, 2011; reviews: 2; accepted: July 25, 2011.

\section{ABSTRACT}

In 2009 the UN Committee on the Rights of the Child denoted the emergence of the widespread practice, conceptualized broadly as "participation". Participation of children in the conduct of public affairs is a concept which evolved from the practices of the state parties to the UN Convention on the Rights of the Child. This concept implies that children have limited opportunities to take part in decision-making processes, concerning those political and public matters which affect their interests. We define what are the ambits of this right as set forth by the UN Convention on the Rights of the Child, what are the major problems in its implementation in state parties to this convention, as well as which measures are recommended by the international treaty bodies to implement this right.

Although the UN Committee on the Rights of the Child follows with its regular inquiries, if this right is implemented at the national level in state parties to the CRC, regional organizations are not bound by the provisions of the universal treaties. Keeping in mind that the emergence of any right at the universal level originates in national practices, we pursue also the second major goal, i.e. to check out whether regional human rights law also mentions the right of the child to participation. This article examines whether regional human 
rights instruments reflect the developments at the universal level of human rights regulation concerning participation of children in political decision-making. Our findings reveal that the scope of childrens' participatory rights is the widest at the level of the Council of Europe. Legal regulation of children's participatory rights at the level of other regional organizations is rather limited in its scope, if at all exists.

\section{KEYWORDS}

Children's rights, universal participatory standards, participation in decision-making, Convention on the Rights of the Child, regional human rights law 


\section{INTRODUCTION}

The first time the question about the existence of children's political rights was officially dealt with by an international human rights body was in 1987 . The European Commission of Human Rights considered the case of CederbergLappalainen v. Sweden. ${ }^{1}$ The Commission questioned, among other things, the legitimacy of a demonstration supporting the idea of peace in the world where children were active participants. Organized by public authorities, that demonstration involved children whose age clearly had not allowed them to form an opinion of their own concerning such serious matters. Upon these grounds the application of Irkka Cederberg-Lappalainen was found inadmissible. The Commission did not consider the issues of children's political participation in fullest possible detail. Nonetheless, the problem of whether children should or should not have limited political rights was identified. Several years later the UN introduced a treaty which answered positively to the question whether children should have political rights, at least limited political rights. It was the UN Convention on the Rights of the Child (the CRC). ${ }^{2}$ In this treaty the CRC Committee notes the emergence of the widespread practice, conceptualized broadly as "participation". ${ }^{3}$ In pursuit of whether the children in state parties to the CRC are provided opportunities to engage in political decision-making, this article uses the praxis of this Committee addressing various state parties to the CRC. Due to the fact that the public participation of children is an evolving concept, the information concerning the relative practices is only infrequently to be found state periodic reports to this Committee. Addressing the information about the implementation of article 12 of the CRC, providing for the right to be heard, this article analyzes all state periodic reports to the CRC Committee, available at the website "Bayefsky". ${ }^{4}$ This article

\footnotetext{
${ }^{1}$ Irka Cederberg-Lappalainen vs. Sweden, European Commission of Human Rights of Human Rights, Appl. No. 11356/85 (1987) [inadmissible; reproduced at the ECtHR portal: http://cmiskp.echr.coe.int/tkp197/search.asp?skin=hudoc-en].

${ }^{2}$ Convention on the Rights of Child (CRC), September 2, 1990, 1577 UNTS 3, art. 43; reproduced at the web-page of the Office of the UN Commissioner for Human Rights:

http://www2.ohchr.org/english/law/crc.htm. The detailed analysis of the CRC provisions is outside the scope of this article. If interested, see, for example: Lawrence J. Le Blanc, The Convention on the Rights of the Child (Lincoln: University of Nebraska Press, 1995); Sara Muscroft, ed., Children's Rights: Reality or Rhetoric? The UN Convention on the Rights of the Child: the First Ten Years (London: the International Save the Children Alliance, 1999), Eugeen Verhellen, Convention on the Rights of the Child: Background, Motivation, Strategies, Main Themes (Antwerp-Apeldoorn: Garant, 2000).

3 The right of the child to be heard, UN Committee on the Rights of the Child, General Comment No. 12 (2009), UN Doc. CRC/C/GC/12 [reproduced at: http://www.bayefsky.com], para. 3. Acknowledging practical difficulties to provide detailed information about initial places of publication of the UN documents and giving due to high quality of the website "Bayefsky" we address this website as the source of publication of the praxis of the CRC Committee.

${ }^{4}$ Website "Bayefsky": http://www.bayefsky.com. According to the information from this website, it was designed for the purpose of "enhancing the implementation of the human rights legal standards of the United Nations. Bayefsky.com was created through the financial support of the Ford Foundation. Research funds were also provided by the Andrew W. Mellon Foundation. The section of the website
} 
illustrates its narratives with those state reports and Concluding Observations of the CRC Committee, which tackle our topic in the most accurate and explicit manner.

This study focuses on children's limited opportunities to take part in decisionmaking concerning political issues. ${ }^{5}$ "Participation" here means the meaningful involvement of children in decision-making processes concerning those political matters which affect them with the goal of exchanging views between children and public officials. Meaningful involvement implies that children participate in politics actively and directly, as much as possible; their views should be duly considered and used as orientations for the development of public policies. It is obvious that only minors who are at a certain level of maturity, assessed on a case-by-case basis, should be given the opportunity to express their views about public policies. By virtue of utilizing the right to express one's views, the right to assembly and association, as well as the right to information, children can let the authorities know about their attitudes towards political matters. Although there are cases when individuals who have not yet attained eighteen years of age are entitled to voting rights, ${ }^{6}$ we cannot conclude on the basis of the experience of a few states that the right of a child to vote exists as a universal human right. This is due to the fact that article 25 of the ICCPR ${ }^{7}$ is subject to reasonable restrictions of the right to take part in the conduct of public affairs which also concern age. As for particular modes other than elections in which the participatory rights of minors can be realized, their thorough analysis is left outside the scope of this article. Hence, research efforts here are focused on the evolving concept of children's participation in limited political issued on the universal level of human rights regulation. Prior to this, commentary is provided on why it is important that minors are engaged in certain

entitled "How To Complain About Human Rights Treaty Violations" was supported by the Consultative Council of Jewish Organizations, London, U.K. Funding is also gratefully acknowledged from The Jacob Blaustein Institute, New York and from the Canadian Department of Foreign Affairs and International Trade".

${ }^{5}$ In accordance with the universal human rights standards, the child means an individual whose age is below 18 years. The terms "the child" and "the minor" are used as synonyms for the purposes of this article.

${ }^{6}$ Among such countries is Iran where the minimum age to vote in elections is 16 years (Initial Report of Iran (Islamic Republic of), UN Committee on the Rights of the Child, July 23, 1998, UN Doc. CRC/C/41/Add.5 (1997), para. 4 (e)). Though in Austria children are excluded from voting in elections, there are two exceptions from this rule. Firstly, children and adolescents have an indirect effect on the composition of the Austrian Parliament. Particularly, the Nationalrat election regulations allocate seats according to population figures (which include children and adolescents) and not the number of those entitled to vote (Initial Report of Austria, UN Committee on the Rights of the Child, June 26, 1997, UN Doc. CRC/C/11/Add.14, para. 79). Secondly, adolescents who have attained the age of 16 can vote in municipal council elections in Burgenland, Carinthia, and Styria (Second Periodic Report of Austria, UN Committee on the Rights of the Child, July 8, 2004, UN Doc. CRC/C/83/Add.8, para. 99). The Isle of Man also allows minors aged 16 to vote in elections in Isle of Man House of Keys Elections (Third and Fourth Periodic Reports of the United Kingdom of Great Britain and Northern Ireland, UN Committee on the Rights of the Child, February 25, 2008, UN Doc. CRC/C/GBR/4, the Isle of Man, para.4). All cited periodic reports are reproduced at the website "Bayefsky": http://www.bayefsky.com.

${ }^{7}$ Which provides for the right to take part in the conduct of public affairs, to vote, and to have access to the public service. 
political issues. Also the article examines regional human rights instruments in pursuits to find out whether there is any mentioning of participatory rights in them. Strictly speaking, there is no obligation for any regional organization to be bound by the provisions of the CRC, as only states are the parties of universal human rights instruments. The United Nations cannot hold regional organizations legally accountable for drafting such regional instruments which would not comply with the provisions of central human rights instruments. Nonetheless, owing to the fact that almost all UN member states ratified the CRC, they cannot introduce regional human rights protection which would be below international standards. There are researchers who maintain that regional social and legal practices that violate universal human rights undermine the goals of regional organizations. ${ }^{8}$ This is due to their observation that regional treaty organizations, as a rule, undertake, among other things, to protect human rights which are universal in character. Accordingly, regional human rights protections systems should respect and observe universal human rights, as it is reflected in the praxis of the Inter-American Court of Human Rights. ${ }^{9}$ Those cases where other regional courts directly refer to universal human rights instruments, as Biakotozky notes, also testify to the evolving tendency for regional organizations to respect universal human rights standards. ${ }^{10}$ Nonetheless, the participatory rights of the child are not always explicitly guaranteed by regional human rights instruments. The lack of certain normative provision does not as such mean that the universal standards of human rights protection are neglected by the states. Hence we try to find verifiable information regarding legal and social practices in the member states of regional organizations which could prove the acknowledgement or, on the contrary, the ignorance of this right in practice.

\section{WHY CHILDREN'S PARTICIPATION?}

Participation in political decision-making is based on the right to take part in the conduct of public affairs, guaranteed by article 25 of the ICCPR. As far as this

\footnotetext{
${ }^{8}$ See, for example: John King Gamble, Teresa A. Bailey, Jared S. Hawk, and Erin E. McCurdy, "Human Rights Treaties: a Suggested Typology, an Historical Perspective," Buffalo Human Rights Law Review 7 (2001): 39; Mary Caroline Parker, "'Other Treaties': the Inter-American Court of Human Rights Defines its Advisory Jurisdiction," American University Law Review 33 (1983); W. Michael Reisman, "Practical Matters for Consideration in the Establishment of a Regional Human Rights Mechanism: Lessons from the Inter-American Experience," Saint Louis-Warsaw Transatlantic Law Journal 89 (1995): 98.

${ }^{9}$ For example the Inter-American Court of Human Rights declared that the advisory jurisdiction of the Court can be exercised regarding "any provision dealing with the protection of human rights set forth in any international treaty applicable in the American States". In other words, the Court declared that it can interpret the treaties which are not only regional but universal in scope ('Other Treaties' Subject to the Consultative Jurisdiction of the Court (Art. 64, American Convention on Human Rights), InterAmerican Court of Human Rights, Advisory Opinion No. OC- /82 (1982), Inter-Am. Ct. of Human Rights, Sept. 24, 1982, para. 52; reprinted in 3 HUM. RTS. L.J. 140 (1982); reproduced at the official web-page of the Inter-American Court of Human Rights: http://www.corteidh.or.cr/opiniones.cfm).

10 See, for example, Noah Biakotozky, "Overcoming Collective Action Failure in the Security Council: would Direct Regional Representation better Protect Universal Human Rights?" Buffalo Human Rights Law Review 15 (2009): 34.
} 
right, as a rule, belongs only to those who have reached the age of eighteen, it is inapplicable for children. Nonetheless, absolute exclusion of minors from political decision-making would be contrary to the principle of citizens' participation in the process of good governance.

The child's perspective on public policies is a topic which has not received much attention in academic literature. Researchers studying the participation of minors in various spheres of human activity maintain that children's engagement in the conduct of public policies is significant. Dealing with the participation of children in health-care decision-making and deriving participatory entitlements from art. 12 of the CRC, Donnelly and Kilkelly suggest three main reasons justifying such participation. These reasons are: the valuable contribution of children's participation in protection and promotion of children's rights; the provision by children of such valuable arguments for or against state policies which can remain latent for adults; and finally the necessity of fulfilling legal obligations under art. 12 of the CRC as well as the central provisions of this treaty. ${ }^{11}$ Similar reasoning is provided by Birnbaum and Bala, who study the rights of children to participate in custody and access cases. ${ }^{12}$ Partially dealing with participation in decision-making through the realization of children's freedom of expression, Langlaude also remarks that children can add on the conduct of public policy, revealing their attitudes to public policies and developing their social skills. ${ }^{13}$

Rutherford, for instance, observes that minors sixteen years of age are mature enough to consciously make political choices. ${ }^{14}$ However, due to such factors as limited financial resources and social experience, and the emotional impulsivity relative to some teenagers, as well as a weaker capacity of organizing themselves for lobbying, minors cannot realize their decisions. ${ }^{15}$ Even when teenagers address public authorities in letters, via TV channels or in any other modes, such addresses are most likely to remain unconsidered in absence of legal mechanisms supporting consideration of children's views. Amidst such events, the opinion of this segment of population is uncounted against the rationale to reach consensus among all the social groups when making political decisions. At the same time, minors as a social subgroup are much affected by public policies, for example, in the area of education or health-care. Hence, specific rights and legitimate

\footnotetext{
11 Mary Donnelly and Ursula Kilkelly, "Child-Friendly Healthcare: Delivering on the Right to be Heard," Medical Law Review 19 (2011): 33.

12 Rachel Birnbaum and Nicholas Bala, "Judicial Interviews with Children in Custody and Access Cases: Comparing Experiences in Ontario and Ohio," International Journal of Law, Policy and the Family 24 (2010): 300-331.

13 Sylvie Langlaude, "On how to Build a Positive Understanding of the Child's Right to Freedom of Expression," Human Rights Law Review 10 (2010): 36-37.

14 Jane Rutherford, "One Child, One Vote: Proxies for Parents," Minnesota Law Review 2 (1998): 1472.

15 Ibid.
} 
interests of children belonging to one of the most vulnerable social groups ${ }^{16}$ should also be counted in the process of public decision-making. Practiced otherwise, political decision-making can cause severe human rights violations and undermine the fundamentals of democracy. It can be proven, for instance, with the saddest experiences of the period up to the late 1970s when aboriginal children were forcefully taken away from their parents to the institutions. ${ }^{17}$ The dubious goal of unification with a mass culture and way of life was pursued at the price of nullifying these children's personal autonomy and neglecting the set of rights belonging to them, their parents and the indigenous community.

Even those who are younger than 16 years of age should also be provided with opportunities to share their opinions in certain issues, related to politics. Their participation in politics would match the scheme of Barber who claims that decisionmaking, based on democratic principles, "educate" people. ${ }^{18}$ The necessity of school children to be engaged in politics is one of the elements of individual political socialization which develops early in life. ${ }^{19}$ Accordingly, it is important to develop in children civic skills and feeling of social responsibility and a duty to obey legal rules. The development of such skills is unthinkable without meaningful exchanges between the children and representatives of the state, realized, for example, via children's parliaments where children act as real parliamentarians, contemplating about real political problems, affecting them.

Hence, to partially balance the reasonable limitation of electoral rights on the basis of age, children should be provided alternative opportunities to express their views on political matters affecting them, and their views should be given due weight by public authorities. And such is the approach of the Convention on the Rights of the Child (the $C R C$ ), entitling minors to the rights to participate in

16 Children are mentioned as belonging to the "vulnerable social groups"; for example, see Forced Evictions, and the Right to Adequate Housing, UN Committee on Economic, Social and Cultural Rights, General Comment No. 7, UN Doc. E/1998/22, annex IV at 113 (1997) [reprinted in Compilation of General Comments and General Recommendations Adopted by Human Rights Treaty Bodies, UN Doc. HRI/GEN/1/Rev.6 at 45 (2003)], para. 10; the same is mentioned also in: The Right to the Highest Attainable Standard of Health, the UN Committee on Economic, Social and Cultural Rights, General Comment No. 14, UN Doc. E/C.12/2000/4 (2000) [reprinted in Compilation of General Comments and General Recommendations Adopted by Human Rights Treaty Bodies, UN Doc. HRI/GEN/1/Rev.6 at 85 (2003)], para. 12 (b). Both General Comments are reproduced at the website "Bayefsky": http://www.bayefsky.com.

17 See, for example: Barbara Atwood, "The Voice of the Indian Child Strengthening the Indian Child Welfare Act through Children's Participation," Arizona Law Review 50 (2008).

18 Benjamin Barber proposes the idea of "Strong Democracy". As the idea of Habermas about "Deliberative Democracy", strong democracy of Barber rests on the necessity of deliberation, i.e. continuous strong democratic talk between the individuals and the state. However, unlike Habermas suggesting the "consensus oriented" goal of deliberations, Barber claims that the final aim of strong democracy is "transformation" of masses pursuing individual interests into "citizens" who are after communal goals and values. Minors' participation in public decision-making and thus learning the necessary civic skills would fit this scheme, according to which deliberative talks have also educational value (Benjamin Barber, Strong Democracy: Participatory Politics for a New Age (Berkeley: University of California Press, 1990)).

${ }_{19}$ Tom R. Tyler and John M. Darley, "Building a Law-Abiding Society: Taking Public Views about Morality and the Legitimacy of Legal Authorities into Account when Formulating Substantive Law," Hofstra Law Review 28 (2000): 721. 
decision-making, be it even a consultative engagement without a compulsory vote. As far as introduction of limited participatory opportunities for children makes certain input in strengthening of good governance, we can say that participatory rights of minors are logical consequences of the existence of the right to public participation available for individuals of full age.

\section{UNIVERSAL STANDARDS OF CHILDREN'S PARTICIPATION}

\subsection{PARTICIPATORY RIGHTS OF CHILDREN IN THE CONVENTION ON THE RIGHT OF THE CHILD}

The term "universal standards of human rights" became established in international law after the introduction of the Universal Declaration of Human Rights, being "a common standard of achievement" for all people and nations. The operational understanding of the expression "universal standards of children's participatory rights" in this article regards universally recognized legal norms of the CRC in the contexts interpretations given to them by the CRC Committee. This term is used following the CRC Committee, addressing in its general comments to the "principles and standards of the Convention". ${ }^{20}$

Thus, at the universal level of legal regulation the CRC entitles children with limited opportunities to participate in decision-making. This most widely ratified convention has several provisions concerning participation. Without making a distinction between civil and political and economic, social and cultural rights, this instrument guarantees the following participatory rights and freedoms. It does not draw any specific line between the freedom of peaceful assembly and the freedom of association. Unlike the ICCPR, the CRC regulates these freedoms by virtue of one legal provision of art. 15. The CRC also guarantees other participatory rights: the right to express one's views freely and opportunity to be heard in any judicial and administrative proceedings affecting the child (art. 12); the right to freedom of expression; this right shall include freedom to seek, receive and impart information and ideas of all kinds (art. 13); the right of the child to freedom of thought, conscience and religion (art. 14); access to information and material from a diversity of national and international sources (art. 17); and the right to education (art. 28).

The explicit references to participation in decision-making can be found in article 12 of the convention. Although the term "participation" is not used in this article, this term has evolved and is used to describe "ongoing processes, which

20 See, for example, UN Committee on the Rights of the Child, General Comment 12, supra note 3, paras. $22,37,68$. 
include information-sharing and dialogue between children and adults based on mutual respect". ${ }^{21}$ Article 12 refers to the expression of children's "views":

1. States Parties shall assure to the child who is capable of forming his or her own views the right to express those views freely in all matters affecting the child, the views of the child being given due weight in accordance with the age and maturity of the child.

2. For this purpose, the child shall in particular be provided the opportunity to be heard in any judicial and administrative proceedings affecting the child, either directly, or through a representative or an appropriate body, in a manner consistent with the procedural rules of national law.

The overall meaning of this article as interpreted by the CRC Committee addresses the participatory claims of children regarding decision-making processes. The views expressed by children "may add relevant perspectives and experience" and should be considered "in decision-making, policymaking and preparation of laws and/or measures as well as their evaluation."22 Moreover, the concept of participation implies not only a momentary inclusion of children in decision-making but it should be a continuous process of a children-adult dialogue "on the development of policies, programmes and measures in all relevant contexts of children's lives". ${ }^{23}$ This does not imply the realization of "classic" participatory rights, such as taking part in the conduct of public affairs; to vote and to stand for elections or for public office (stipulated by art. 25 of the ICCPR). Nonetheless, this article gives entitlements for children to engage in decision-making which directly affect their rights and interest. It can be practiced, for example, by the opening of governmental sessions for children, organizing children's parliaments, or strengthening the activities of children's associations.

\subsection{SPECIFYING UNIVERSAL STANDARDS}

General Comment 12 of the CRC Committee is entirely devoted to the right of the child to be heard. It gives interpretations to several important provisions of article 12 . With the general reference to the right guaranteed by this article it emphasizes that it imposes a legal obligation "to recognize this right and ensure its implementation by listening to the views of the child and according them due weight". ${ }^{24}$ This obligation requires that states with respect to their particular judicial system either directly guarantee this right or adopt or revise laws so that this right can be fully enjoyed by the child. Considering the free and consensual nature of

\footnotetext{
${ }^{21}$ Ibid., para. 3.

22 Ibid., para. 12.

${ }^{23}$ Ibid., para. 13.

${ }^{24}$ Ibid., para. 15.
} 
participation, the Committee notes that the child has the right not to exercise this right. Expressing views is a choice for the child, not an obligation. ${ }^{25}$

Giving specification on separate clauses of this article, the CRC Committee contributes to the due implementation of international standards. The clause "shall ensure" is "a legal term of special strength, which leaves no leeway for State parties' discretion". ${ }^{26}$ Moreover, the phrase "capable of forming his or her views" should not be counted as a limitation. It is rather an obligation "to assess the capacity of the child to form an autonomous opinion to the greatest extent possible". ${ }^{27}$ This also implies that the states should assist those children who have difficulties to express their views due to the disabilities or not knowing of the state language. "The right to express those views freely" means that the child should express his or her views without any coercion, manipulation, according to the personal conditions and situation. The child should also be informed about the consequences of the expression of the views and the possible options of the decisions. ${ }^{28}$ Participation in "in all matters affecting the child" should be understood broadly, "which also covers issues not explicitly mentioned in the Convention". ${ }^{29}$ This clause provides the possibility to also express views on political issues affecting children. The expression that the views of the child must be "given due weight in accordance with the age and maturity of the child" implies that those views have to be assessed in order to give due weight to them or "to communicate to the child the way in which those views have influenced the outcome of the process". ${ }^{30}$ The feedback is "a guarantee that the views of the child are not only heard as a formality, but are taken seriously". ${ }^{31}$ The requirement of the child's maturity implies that the assessment of his or her views can not be done on the basis of mere age criteria. "Maturity" refers to "the ability to understand and assess the implications of a particular matter, and must therefore be considered when determining the individual capacity of a child". ${ }^{32}$ The clause "to be heard in any judicial and administrative proceedings affecting the child" means the following. Relevant judicial proceedings affecting the child are outlined ${ }^{33}$ as well as typical

\footnotetext{
25 Ibid., para. 16.

${ }^{26}$ Ibid., para. 19.

27 Ibid., para. 20.

${ }^{28}$ Ibid., paras. 22-25.

${ }^{29}$ Ibid., paras. 26-27.

${ }^{30}$ Ibid., para. 28.

31 The information may prompt the child to insist, agree or make another proposal or, in the case of a judicial or administrative procedure, file an appeal or a complaint (ibid., para. 45).

32 Ibid., para. 30.

33 They are without limitation, including, for example, separation of parents, custody, care and adoption, children in conflict with the law, child victims of physical or psychological violence, sexual abuse or other crimes, health care, social security, unaccompanied children, asylum-seeking and refugee children, and victims of armed conflict and other emergencies (ibid., para. 32).
} 
administrative proceedings. ${ }^{34}$ Both kinds of proceedings may involve alternative dispute mechanisms such as mediation and arbitration. Proceedings must be both accessible and child-appropriate. ${ }^{35}$ States parties are encouraged to introduce legislative measures requiring decision makers in judicial or administrative proceedings to explain the extent of the consideration given to the views of the child and the consequences for the child. ${ }^{36}$ The mentioning of the participation "either directly, or through a representative or an appropriate body" has several implications. Firstly, the child decides him or herself whether to be heard in judicial or administrative procedure or not. ${ }^{37}$ The possibility of the conflict of interests between the child and the representative is also considered. The solutions to overcome them are suggested. ${ }^{38}$ Secondly, the Committee specifies who can be a representative of the child. ${ }^{39}$ The clause "in a manner consistent with the procedural rules of national law" should not be interpreted as permitting the use of procedural legislation, which restricts or prevents enjoyment of this fundamental right. $^{40}$

\subsection{COMMON BARRIERS IN REALIZATION OF CHILDREN'S PARTICIPATORY RIGHTS}

Although states are required to introduce all kinds of possible measures to ensure children's participation, the analysis of the praxis under article 12 of the CRC reveals many problems in realization of this right. As an overall observation, the contents of states reports to the CRC Committee with respect to children's participation quite often lack precision. For example, information concerning the realization of freedoms of expression, assembly and association is provided in general terms without specific references to children. ${ }^{41}$ Sometimes states reporting on the realization of these freedoms by children, e.g. on the enactment of laws, give extremely limited information concerning these laws by merely bringing the

\footnotetext{
34 Which include, for example, decisions about children's education, health, environment, living conditions, or protection (ibid.).

35 Ibid., para. 34.

${ }^{36}$ Ibid., para. 33.

${ }^{37}$ Ibid., para. 35.

${ }^{38}$ Among such solutions are: the necessity for a representative to remember that he or she represents the interests of the child, not the own interests, not the interest of any institution or person, development of the codes of conflict, thorough knowledge of various aspects of decision-making processes (ibid., paras. 36, 37).

${ }^{39}$ It can be the parent(s), a lawyer, or another person (inter alia, a social worker) (ibid., para. 36).

${ }^{40}$ Ibid., para. 38.

41 Initial Report of Andorra, UN Committee on the Rights of the Child, 3 July 2001, UN Doc. CRC/C/61/Add.3, para. 157; Second Periodic Report of Austria, supra note 6, para. 227; Second Periodic Report of Canada, UN Committee on the Rights of the Child, 12 March 2003, UN Doc. CRC/C/83/Add.6, para. 90; Initial Report of South Africa, UN Committee on the Rights of the Child, 22 May 1999, UN Doc. $\mathrm{CRC} / \mathrm{C} / 51 /$ Add.2, paras. 176-178. All cited reports are reproduced at the website "Bayefsky": http://www.bayefsky.com.
} 
name of the law to the attention of the CRC Committee. ${ }^{42}$ Although rarely, such cases can be encountered where state reports even contain contradictory statements. ${ }^{43}$ This might be explained by the willingness of states' parties to the CRC to show they keep up with their obligations undertaken in the frames of this convention. However, more precise and clear data provided in a state's report would better contribute to assessment of states compliance with their obligations in respect of children's participatory rights.

Several groups of problems in the realization of children's rights to participation can be identified by virtue of analysis of the CRC Committee's praxis. Traditional culturally biased attitudes towards the role of a child in society are serious obstacles in realization of children's participatory rights, as cultural problems are "a factor which impedes the implementation of these [participatory] rights". ${ }^{44}$ Such attitudes directly result in the non-realization of participatory rights. This may reveal itself, inter alia, in a large discretion of judges deciding upon the opportunities of the child to be heard in the judicial process ${ }^{45}$ or in prevention from direct representation of children's interests in judicial proceedings because of the overwhelming parental representation. ${ }^{46}$ Culturally biased views on children's participation are widely spread in Grenada, Honduras, India, Iran and many other states $^{47}$ where a perception of the child as a "possession" of the parents and an object rather than subject of rights is predominant. Some states openly report about such cultural obstacles. For example, Mali admitted that the ideas of freedom of expression, thought, conscience and religion and respect for the privacy of children "are not easily accepted in Malian society, in which parents are always responsible for children". ${ }^{48}$ Reacting to these and other implications of culturebased limitations of children's participation, the CRC Committee repeatedly

\footnotetext{
42 Concluding Observations on Dominican Republic, UN Committee on the Rights of the Child, UN Doc. CRC CRC/C/103 (2001), para. 32; reproduced at the website "Bayefsky": http://www.bayefsky.com.

43 Ibid., para. 23.

${ }^{44}$ Ibid., para. 21.

45 Concluding Observations on Belgium, UN Committee on the Rights of the Child, UN Doc. CRC A/51/41 (1996), para. 112; Concluding Observations on Lesotho, UN Doc. CRC/C/103 (2001), para. 337; Concluding Observations on Malaysia, UN Doc. CRC/C/MYS/CO/1, para. 42. All cited Concluding Observations are reproduced at the website "Bayefsky": http://www.bayefsky.com.

46 Concluding Observations on Chad, UN Committee on the Rights of the Child, UN Doc. CRC C/87 (1999), para. 183; reproduced at the website "Bayefsky": http://www.bayefsky.com.

47 Concluding Observations on Grenada, UN Committee on the Rights of the Child, UN Doc. CRC CRC/C/94 (2000), para. 398; Concluding Observations on Honduras, UN Doc. CRC A/51/41 (1996), para. 115; Concluding Observations on India, UN Doc. CRC/C/15/Add.228, para. 36; Concluding Observations on the Islamic Republic of Iran, UN Doc. CRC CRC/C/97 (2000), para. 33. All cited Concluding Observations are reproduced at the website "Bayefsky": http://www.bayefsky.com.

${ }^{48}$ Initial Report of Mali, UN Committee on the Rights of the Child, Addendum, 8 September 1997, UN Doc. CRC/C/3/Add.53, para. 23. See also: Second Periodic Report of Chad, Committee on the Rights of the Child, 14 December 2007, UN Doc. CRC/C/TCD/2*, para. 86. Both cited reports are reproduced at the website "Bayefsky": http://www.bayefsky.com.
} 
recommends strengthening states' efforts to change traditional perceptions of children as objects rather than subjects with rights. ${ }^{49}$

Material barriers to implement children's participatory rights in decisionmaking reveal themselves in, e.g., a lack of facilities, or insufficient training of the personnel to deal with child-specific issues. Thus, in the case with Maldives the Committee was concerned that the lack of appropriate sanitary facilities, including separate toilets, impedes the full participation of girls in education, particularly in secondary schools. ${ }^{50}$ Without a minimal level of basic facilities it is impossible to expect the meaningful impact of education on the civil activity of the child. To deal with the situation the Committee puts forward recommendation to make appropriate facilities available for children. ${ }^{51}$ Financial barriers are most often met in realization of the right of the child to participation. Definitely, the CRC Committee can recommend that state parties allocate available and necessary resources and assistance for the realization of this right. ${ }^{52}$ However, the state is not always able to do it. One way of settlement would be to seek for cooperation with international bodies, such as UNICEF, to fulfill the relevant state's obligations. ${ }^{53}$

Legal barriers, i.e. a lack of national legal provisions facilitating children's participatory rights, were noted in Algeria, Kenya, and Malaysia and in many other states. ${ }^{54}$ As a possible solution for this, the committee might recommend, for example, that the state introduces and enforces, where applicable, legislation to facilitate the participatory rights of children. Such legislation should provide children with complaint procedures and remedies "when their right to be heard and for their views to be given due weight is disregarded and violated". ${ }^{55}$

In spite of these problems, "considerable progress has been achieved at the local, national, regional and global levels in the development of legislation, policies

49 Concluding Observations on Costa Rica, UN Committee on the Rights of the Child, UN Doc. CRC/C/15/Add.266, para. 225; reproduced at the website "Bayefsky": http://www.bayefsky.com.

50 Concluding Observations on Maldives, UN Committee on the Rights of the Child, UN Doc. CRC/C/MDV/CO/3, para. 77; reproduced at the website "Bayefsky": http://www.bayefsky.com.

51 Concluding Observations on Benin, UN Committee on the Rights of the Child, UN Doc. $\mathrm{CRC/C/BEN/CO/2),} \mathrm{para.} \mathrm{33;} \mathrm{reproduced} \mathrm{at} \mathrm{the} \mathrm{website} \mathrm{"Bayefsky":} \mathrm{http://www.bayefsky.com.}$

52 See, for example: Concluding Observations on Antigua and Barbuda, UN Committee on the Rights of the Child, UN Doc. CRC/C/15/Add.247, para. 59; Concluding Observations on Iceland, Un Doc. CRC A/51/41 (1996), para. 487 (a); Concluding Observations on Ireland, UN Doc. CRC A/53/41 (1998), para. 1295; Concluding Observations on Nigeria, UN Doc. CRC/C/15/Add.257, para. 18. All cited Concluding Observations are reproduced at the website "Bayefsky": http://www.bayefsky.com.

${ }^{53}$ As it was recommended, for example, in the following cases: Concluding Observations on Egypt, UN Committee on the Rights of the Child, UN Doc. CRC A/49/41 (1994), para. 231; Concluding Observations on Jordan, UN Doc. CRC/C/JOR/CO/3, para. 41; Concluding Observations on Vanuatu, UN Doc. CRC CRC/C/90 (1999), para. 147. All cited Concluding Observations are reproduced at the website "Bayefsky": http://www.bayefsky.com.

${ }^{54}$ Concluding Observations on Algeria, UN Committee on the Rights of the Child, UN Doc. CRC A/53/41 (1998), para. 880; Concluding Observations on Kenya, UN Doc. CRC/C/KEN/CO/2, para. 70 (a); Concluding Observations on Kuwait, UN Doc. CRC CRC/C/80 (1998), para. 137; Concluding Observations on Malaysia, supra note 45, para. 43. All cited Concluding Observations are reproduced at the website "Bayefsky": http://www.bayefsky.com.

55 UN Committee on the Rights of the Child, General comment 12, supra note 3, para. 46. 
and methodologies to promote the implementation of article $12^{\prime \prime} .^{56}$ This progress witnesses the emergence of a widespread practice of "participation". 57

\subsection{SYSTEMATIC APPROACH TO THE REALIZATION OF CHILDREN'S PARTICIPATORY RIGHTS}

Addressing, among other things, the problems around realization of children's participatory rights, the CRC Committee elaborated General Comments No. 5 and No.12. ${ }^{58}$ The following measures to improve the situation with facilitation of these rights are mentioned by General Comment 5: introduction of arrangements for involvement of and consultation with children; making accessible of documents as well as processes of consultations with children; development of a direct relationship with children, not simply one mediated through NGOs (para. 12); strengthening the efforts to provide training on the rights of the child to be practical, systematic and integrated into regular professional training (para. 69). More measures are included in General Comment 12. Among them are: review and withdrawing of restrictive declarations and reservations to article 12; establishment of independent human rights institutions with a broad children's rights mandate; combating the negative attitudes, which impede the full realization of the child's right to be heard, through public campaigns, including opinion leaders and the media, to change widespread customary conceptions of the child. ${ }^{59}$

However, it would be too hasty to conclude that separate implementation measures would effectively solve the issue of respect and the fulfillment of children's participatory rights. All the measures mentioned above ought to be realized in a system in order to achieve the best results. That is the reason why the CRC Committee in many cases recommends several measures for states' parties to fulfill their obligations in respect of children's participatory rights. Quite often the committee proposes a "systematic approach" to the solution of this problem. ${ }^{60}$ For example, in the case of Yemen, the participatory rights of children were not taken

${ }^{56}$ Ibid., para. 3.

57 Ibid.

${ }^{58}$ General Measures of Implementation of the Convention on the Rights of the Child (arts. 4, 42 and 44 , para. 6), UN Committee on the Rights of the Child, General Comment No. 5 (2003), 27 November 2003, UN Doc. CRC/GC/2003/5; reproduced at the website "Bayefsky": http://www.bayefsky.com.

${ }^{59}$ UN Committee on the Rights of the Child, General comment 12, supra note 3, para. 49.

60 The committee puts forward the recommendation to develop systematic approach to ensure participatory rights of children to such states as Fiji, Grenada, Kazakhstan, Lao People's Democratic Republic, Malawi, Mongolia, Niger, and several other states. See: Concluding Observations on Fiji, UN Committee on the Rights of the Child, UN Doc. CRC/C/79 (1998), para. 132; Concluding Observations on Grenada, supra note 47, para. 398; Concluding Observations on Kazakhstan, UN Doc. CRC/C/KAZ/CO/3, para. 31 (b); Concluding Observations on Lao People's Democratic Republic, UN Doc. CRC A/53/41 (1998), para. 997; Concluding Observations on Malawi, UN Doc. CRC CRC/C/114 (2002), para. 410; Concluding Observations on Mongolia, UN Doc. CRC A/51/41 (1996), para. 863; Concluding Observations on Niger, UN Doc. CRC CRC/C/118 (2002), para. 158. All cited Concluding Observations are reproduced at the website "Bayefsky": http://www.bayefsky.com. 
into account "by the society at large". The Committee recommended that the state party should further develop a systematic approach to increasing public awareness, including through the media, of the participatory rights of children in order to make these rights and its implications fully understood by the population at large. ${ }^{61}$ The systematic approach may include various combinations of such measures as ensuring of the compatibility of national legislation to international standards, enacting media and raising public awareness on this matter, changing traditional attitudes towards the role of the child in society, allocation of financial resources, dissemination and promotion of the (CRC) convention, translation of the convention into all languages spoken by minorities living in the state party, or implementation of comprehensive national plan of action for children. ${ }^{62}$ However, the implementation of the systematic approach to deal with participatory rights is highly dependent on financial, human, and other national resources. Probably, such an approach would be absolutely necessary if the situation concerning the denial of participatory children's rights would be deeply rooted in specific traditional and cultural perceptions of society and thus there would be in an urgent need to change the views of society at large. Such situations have existed, for example, in Chad, Guinea, Marshall Islands, Vanuatu, and Yemen.

\section{ARE UNIVERSAL STANDARDS OF CHILDREN'S PARTICIPATION} REFLECTED IN REGIONAL HUMAN RIGHTS INSTRUMENTS?

\subsection{THE LEAGUE OF ARAB STATES}

The age-old traditional practices of Arab states providing the extensive role for the councils of elders applying religious provisions to deal with daily life would propose without exaggeration that children's participation legal regulation of children's participatory rights can be at its minimum at the level of the LAS.

The first human rights instrument within this regional organization was the Arab Charter on Human Rights. ${ }^{63}$ Its revised version was adopted by the LAS and the Charter came into force in $2008 .^{64}$ The adoption of this treaty gave impulse to

\footnotetext{
${ }^{61}$ Concluding Observations on Yemen, UN Committee on the Rights of the Child, UN Doc. CRC A/51/41 (1996), para. 169; reproduced at the website "Bayefsky"// http://www.bayefsky.com.

62 Concluding Observations on Bahrain, UN Committee on the Rights of the Child, UN Doc. CRC CRC/C/114 (2002), para. 467 (a); Concluding Observations on Egypt, supra note 53, para. 59; Concluding Observations on Chad, supra note 46, para. 183; Concluding Observations on Finland, UN Doc. CRC A/51/41 (1996), para. 1028; Concluding Observations on Guinea, UN Doc. CRC CRC/C/84 (1999), para. 108; Concluding Observations on Vanuatu, supra note 53, para. 150. All cited Concluding Observations are reproduced at the website "Bayefsky": http://www.bayefsky.com.

${ }^{63}$ Arab Charter on Human Rights, Council of the League of Arab States, Adopted on September 15, 1994 [not in force; reprinted in 18 Hum. Rts. L.J. 151 (1997)]; reproduced at the website of University of Minnesota, Human Rights Library: http://www1.umn.edu/humanrts/instree/arabhrcharter.html.

${ }^{64}$ Arab Charter on Human Rights, League of Arab States, Adopted on May 22, 2004 [reprinted in 12 Int'I Hum. Rts. Rep. 893 (2005); entered into force March 15, 2008]; reproduced at the Arab Human Rights
} 
the creation of human rights protection system within the League. However, in response to its entrance into force, the UN High Commissioner for Human Rights, Louise Arbour, pointed out that the Charter is still incompatible with international standards for women's, children's and non-citizens' rights. Following the words of the High Commissioner, "OHCHR does not endorse these inconsistencies. We continue to work with all stakeholders in the region to ensure the implementation of universal human rights norms". ${ }^{65}$ The major critique of the provisions of this Charter concerns the issues of the death penalty which can be inflicted on a person under 18 years of age if it is "provided by the law in force at the time of the commission of the crime" (article 7, para. 1). This provision clearly does not comply with article $37(a)$ of the CRC, nor is it in conformity with article 6, para. 5 of the ICCPR. Both of these articles contain an absolute prohibition of imposition of death penalty on persons under 18 years of age. The tragic fact of child execution by member states of the LAS, namely, Saudi Arabia and Yemen, is grounded on the provisions of the human rights charter. ${ }^{66}$

Participatory provisions of the Charter cover such aspects as: the right to take part in the conduct of public affairs; the right to form and join associations and to the freedom of association and peaceful assembly (article 24); the right to freedom of thought, conscience and religion (article 30); the right to education (article 41). It is, however, true that there is no separate article dealing with the relevant rights of the child in the Arab Charter, though separate provisions regulating children's rights can be found. ${ }^{67}$ On the contrary, this instrument contains a somewhat restricting provision, in accordance with which "parents or guardians have the freedom to provide for the religious and moral education of their children" (article 30, para. 3).

The control mechanism over the implementation of the Charter provisions is vested in the Arab Human Rights Committee (article 45). The Committee does not

Index, the website of the UNDP: http://www.arabhumanrights.org/en/treaties/bycommittee.aspx. About this Charter see, for example: Lorie M. Graham, "A Right to Media?" Columbia Human Rights Law Review 41 (2010): 472; Mervat Rishmawi, "The Arab Charter on Human Rights and the League of Arab States: the Update," Human Rights Law Review 10 (2010): 170.

${ }^{65}$ On the Entry into force of the Arab Charter on Human Rights, Statement by UN High Commissioner for Human Rights //

http://www.unhchr.ch/huricane/huricane.nsf/view01/6C211162E43235FAC12573E00056E19D?opendocu ment.

66 See: Stop Child Executions! Ending the Death Penalty for Child Offenders, Amnesty International, Report (September 15, 2004), ACT 50/015/2004; reproduced at the website of Amnesty International: http://www.amnesty.org/en/library/info/ACT50/015/2004/en.

67 For example, article 10 of this instrument contains prohibition of the exploitation of children in armed conflict. The right to be protected from economic exploitation and from performing any work that is likely to be hazardous or to interfere with the child's education, or to be harmful to the child's health or physical, mental, spiritual, moral or social development, is guaranteed by article 34 of this instrument. According article 33, para. 3 of the charter the states parties take all necessary measures "to guarantee the protection, survival, development and well-being of the child" and ensure that "the child's best interests are the basic criterion for all measures taken in his regard, whether the child is at risk of delinquency or is a juvenile offender". 
deal with the individual communications. Owing to the fact that this Committee was established only in $2009{ }^{68}$ there is no praxis information available so far. Addressing, for example, the 2009 Arab Human Rights Report, ${ }^{69}$ drafted after the coming into force of the Arab Charter on Human Rights, it is possible to witness that the Charter application is not adequately observed. Such facts as prohibition of political parties in six Arab countries or lack of channels for representative political participation $^{70}$ witness to the fact that general participatory rights are poorly implemented. As for children's participation, it does not seem to be the only leading unresolved human rights issue. The tragic facts about violence against children, child marriages, female genital mutilation, honor crimes, rapes, human trafficking and the condition of children in theatres of conflict unintentionally move the participatory thematic out of the focus. ${ }^{71}$ Basic conditions of personal security and adequate standard of living are not duly met in the Arab region.

It remains to be seen whether the Charter inconsistencies with international law and the basic rights' implementation are brought into conformity with the universal human rights standards. It is still possible, however, to meet the application in the very restricting manner of the universally recognized principle of the "best interest of the child" in the Charter. ${ }^{72}$ At least the formal appearance of such provisions represents an effort to implement universal standards. It fits researchers' observation stating that the dependency of national human rights law on cultural traditions is not static; it "reflects societal realities at particular points in time". ${ }^{73}$

\subsection{THE ORGANIZATION OF AMERICAN STATES}

Several instruments deal with the rights of the child at the level of the Organization of American States (the OAS). The American Declaration of the Rights and Duties of Man (1948) $)^{74}$ provides that all children have the right "to special

\footnotetext{
${ }^{68}$ About the Arab Human Rights Committee see, for example: Mervat Rishmawi, supra note 64.

69 Arab Human Development Reports are drafted under the aegis of the United Nations Development Programme.

${ }^{70}$ Challenges to Human Security in the Arab Countries, Arab Human Development Report 2009, United Nations Development Programme; reproduced at the website of UNPD, Arab Human Development Reports: http://www.arab-hdr.org/contents/index.aspx?rid=5.

${ }^{71}$ Ibid., 79-89.

72 For example, dealing with the issues concerning women's executions, the Charter prohibits, following this principle, executions of pregnant women and nursing mothers (article 7, para. 2). The same principle should be also taken into account when deciding upon a possibility to acquire mother's nationality by a child (article 29, para. 2); when providing measures to guarantee protection, survival and well-being of a child (article 33, para. 3); and when providing social services for persons disabilities (article 40, para. 2).

73 See: Kathryn Hay, "A Pacific Human Rights Mechanism: Specific Challenges and Requirements," Victoria University of Wellington Law Review 40 (2009): 201-202.

74 American Declaration of the Rights and Duties of Man, O.A.S. Res. XXX, Adopted by the Ninth International Conference of American States (1948) [reprinted in Basic Documents Pertaining to Human
} 
protection, care and aid". Similarly, the American Convention on Human Rights contains provisions concerning the rights of the child. ${ }^{75}$ If a State has not ratified the American Convention, the American Declaration on the Rights and Duties of Man is applied. A bit further in the scope of its legal regulation of this matter goes the Additional Protocol to the American Convention on Human Rights in the Area of Economic, Social and Cultural Rights ("Protocol of San Salvador"). ${ }^{76}$

As for the participatory rights of children, the provisions of article 13 of the American Convention and 27 of the Inter-American Democratic Charter can give rise to them. Article 13, para. 2 of the American Convention provides that "education ought to enable everyone to participate effectively in a democratic and pluralistic society". Whereas article 27 of the Charter mentions that:

The objectives of the programs and activities will be to promote good governance, sound administration, democratic values, and the strengthening of political institutions and civil society organizations. Special attention shall be given to the development of programs and activities for the education of children and youth as a means of ensuring the continuance of democratic values, including liberty and social justice.

The control mechanism over the implementation of the American Convention on Human Rights is exercised via the Inter-American Commission on Human Rights. However, complaints to the Commission may be brought only to the Member States of the OAS. Similarly, access to the Inter-American Court of Human Rights with the complaints is open only to the Inter-American Commission and States Parties to the American Convention. Nevertheless, the issues of children's participatory rights have been a subject matter of the Court's consideration. In 2002 the InterAmerican Court of Human Rights delivered the Advisory Opinion OC-17/2002 ${ }^{77}$ on

Rights in the Inter-American System, OEA/Ser.L.V/II.82 doc.6 rev.1 at 17 (1992)], art. VII; reproduced at the website of the University of Minnesota Human Rights Library:

http://www1.umn.edu/humanrts/oasinstr/zoas2dec.htm.

75 According to article 19 of the convention, "[e]very minor child has the right to the measures of protection required by his condition as a minor on the part of his family, society, and the state" (American Convention on Human Rights, OAS Treaty Series No. 36, 1144 UNTS 123, entered into force July 18, 1978 [reprinted in Basic Documents Pertaining to Human Rights in the Inter-American System, OEA/Ser.L.V/II.82 doc.6 rev.1 at 25 (1992)], reproduced at the website of the University of Minnesota Human Rights Library: http://www1.umn.edu/humanrts/oasinstr/zoas3con.htm).

76 Within the frames of its article 15 (right to the formation and the protection of families) states parties undertake to accord adequate protection to the family unit and in particular: to guarantee adequate nutrition for children; to adopt special measures for the protection of adolescents in order to ensure the full development of their physical, intellectual and moral capacities; to undertake special programs of family training so as to help create a stable and positive environment in which children will receive and develop the values of understanding, solidarity, respect and responsibility (paras. b, c, and d). More elaborate are the provisions of article 16 of the protocol which states that every child has the right to the protection "that his status as a minor requires from his family, society and the State". Moreover, he or she has the right to free and compulsory education. Article 17 provides for the necessity of establishment of a special system to deal with the juvenile delinquency.

77 Juridical Condition and Human Rights of the Child, Inter-American Court of Human Rights, Advisory Opinion OC-17/2002 (2002) [requested by the Inter-American Commission on Human Rights, Inter-Am. Ct. H.R. (Ser. A) No. 17 (2002)]; reproduced at the website of the Inter-American Court of Human Rights: http://www.corteidh.or.cr/docs/opiniones/seriea_17_ing.pdf. 
the issues of legal conditions and human rights of the child. Children's participation represented a separate issue in this opinion. This opinion was requested by the Inter-American Commission on Human Rights regarding the interpretation of Articles 8 (right to a fair trial) and 25 (right to juridical protection) of the American Convention, with the aim of determining whether the special measures set forth in Article 19 of this convention (the measures of protection required by his condition as a minor on the part of his family, society, and the state) establish "limits to the good judgment and discretion of the States" with respect to children. It also requested that the Court express general and valid criteria on this matter in conformance to the framework of the American Convention. International organs dealing with human rights of the child refer to this comprehensive document covering important aspects of children's rights. ${ }^{78}$ Several important issues are raised in this Advisory Opinion. Firstly, the court highlighted the existence of a "very comprehensive international corpus juris for the protection of the child" (which the CRC and the American Convention are part of), which should be used as a source of law by the Court to establish "the content and scope" of the obligations undertaken by the State through the American Convention, specifically with respect to identification of the "measures of protection" to which the aforementioned precept refers (para. 24). Secondly, the degree of participation of a child in the proceedings must be reasonably adjusted, so as to attain effective protection of his or her best interests, which are the ultimate objective of international human rights law in this regard (para. 101). Thirdly, those responsible for application of the law must take into account the specific conditions of the minor and his or her best interests to decide on the child's participation, as appropriate, in establishing his or her rights (para. 102).

\subsection{THE AFRICAN UNION}

Participatory rights of children are quite extensively guaranteed by the African Charter of the Rights and Welfare of the Child at the level of the African Union (the $\mathrm{AU}){ }^{79}$ Minors' participatory rights are regulated in a manner much like the CRC at the UN level. ${ }^{80}$ For instance, the wording of article 12 of the African Charter of the Rights and Welfare of the Child, dealing with the right of the child to participate freely in cultural life, is identical to that of article 31 of the CRC.

\footnotetext{
78 See, for example: The Right of the Child to Protection from Corporal Punishment and other Cruel or Degrading Forms of Punishment (arts. 19; 28, para. 2; and 37, inter alia), UN Committee on the Rights of the Child, General Comment No. 8 (2006), UN Doc. CRC/C/GC/8, para. 24; reproduced at the website "Bayefsky": http://www.bayefsky.com.

79 The African Charter on the Rights and Welfare of the Child, Organization of African Unity, OAU Doc. CAB/LEG/24.9/49 (1990), entered into force November 29, 1999; reproduced at the website of the Organization of African Unity: http://www.au.int/en/treaties.

80 Ibid.
} 
The opportunity to communicate his or her views is fixed by article 4 of the charter devoted to the best interest of the child. As stated in paragraph 2 of the above-mentioned article:

In all judicial or administrative proceedings affecting a child who is capable of communicating his/her own views, and opportunity shall be provided for the views of the child to be heard either directly or through an impartial representative as a party to the proceedings, and those views shall be taken into consideration by the relevant authority in accordance with the provisions of appropriate law.

In contrast with the provisions of article 12 of the CRC, there is no mention of a "due weight" which ought to be given to the views of the child under the condition of such common characteristics as "the age and maturity" in the child welfare Charter. The Charter only contains the provision concerning "consideration" of these views. Moreover, the opportunity to be heard is guaranteed by the CRC for the child "in all matters affecting the child" which imply participation inter alia within the family and other social institutions; although the child welfare Charter mentions, in a restrictive manner, only "judicial and administrative proceedings". The requirement of the CRC to consider the views of the child "in accordance with age and maturity" is also missing from article 4 of the Charter. This also does not necessitate the efforts of state parties to asses the views of the child on "a case-bycase examination" as stipulated by the CRC Committee. ${ }^{81}$

Besides, the child welfare Charter contains a somewhat limited clause concerning the capability of a child to "communicate his/her own views". This is not exactly in line with the CRC, which interprets the requirement of child's maturity rather broadly. For example, the CRC Committee emphasizes that research has shown that the child is able to form views "from the youngest age, even when she or he may be unable to express them verbally". ${ }^{22}$ Besides, unlike the article 12 of the CRC, the literal formulation of the Charter does not imply that states should direct efforts to assist, for instance, children with disabilities with "any mode of communication necessary to facilitate the expression of their views" ${ }^{\prime 83}$ or minority children who do not speak the majority language.

The abovementioned differences between the participatory regulations of the children's participatory rights by the CRC and the African Charter of the Rights and Welfare of the Child, demonstrate that the Charter is more restrictive in comparison with the CRC. This may be explained by strong cultural or traditional attitudes

\footnotetext{
${ }^{81}$ UN Committee on the Rights of the Child, General Comment 12, supra note 3, para. 29.

82 Ibid., para. 21.

${ }^{83}$ Ibid.
} 
towards the role of the child in the society, according to which participatory rights of the child are sometimes limited.

The African Committee of Experts on the Rights and Welfare of the Child with the mandate to receive individual communications was created to monitor the implementation of this Charter. However, the Committee is still adopting its rules of procedure. During its sessions the importance of children's participation are proposed to be included in the future agenda of the Committee's meetings. ${ }^{84}$ Thus, the Committee has not yet considered any reports or complaints.

One more instrument at the level of the $A U$ opens wide opportunities to facilitate children's participation. This instrument is the African Charter on Democracy, Election and Governance. ${ }^{85}$ Adopted in 2007, this Charter is seeking to promote adherence "to the universal values and principles of democracy and respect for human rights". ${ }^{86}$ Although the term "child" is not operative in this Charter's provisions, there are several explicit references to children's' participation. Firstly, article 8 , para. 2 of this instrument provides that state parties shall adopt legislative and administrative measures to guarantee the rights of children as one of the "marginalized" social groups. Secondly, article 31, para. 1 of the African Charter on Democracy, Election and Governance mentions the state parties' obligation to "promote participation of social groups with special needs, including the youth and people with disabilities, in the governance process". This is to be achieved by ensuring "civic education in order to encourage full participation of social groups with special needs in democracy". ${ }^{87}$ Article 43 also addresses children in particular. It sets out the obligation to provide free and compulsory basic education to all, "especially girls, rural inhabitants, minorities, people with disabilities and other marginalized social groups". The realization of "freedom of expression, in particular freedom of the press" ${ }^{\prime 88}$ is another participatory form which may be used for the participation of children. Thus, one may conclude that the participatory scope of this instrument is much wider in comparison with the CRC. Nonetheless, as the African Charter on Democracy, Election and Governance is not yet in force and thus there is no practice of its implementation, one cannot make any judgments concerning the reality of facilitation of children's participation under its provisions.

${ }^{84}$ Report, The African Committee of Experts on the Rights and Welfare of the Child, Eighth Meeting, Addis Ababa, Ethiopia, November 27 -December 1, 2006; reproduced at: http://www.africaunion.org/root/au/Conferences/Past/2006/November/SA/child/Provisional_Agenda.doc.

85 African Charter on Democracy, Election and Governance, African Union, Adopted by the Eighth Ordinary Session of the Assembly, held in Addis Ababa, Ethiopia, January 30, 2007 [according to the information given in the official web-page of the African Union, the Charter is no yet in force] // http://www.africa-union.org/root/au/Documents/Treaties/treaties.htm.

86 Ibid., article 2, para. 1.

87 Ibid., article 31, para. 2.

${ }^{88}$ Ibid., article 27, para. 8. 
The researchers sometimes convey the opinion that, for example the African Charter on the Rights and Welfare of the Child can be "too radical for many African states" which can cause difficulties in its implementation mainly due to culture- and tradition-biased reasons. ${ }^{89}$ Nonetheless, it is impossible to disregard those legal changes towards the observance of human rights that have taken place during the last decades in African states.

\subsection{THE COUNCIL OF EUROPE}

Several child-specific conventions were adopted within the Council of Europe (the CoE). ${ }^{90}$ The idea to adopt special instruments on children's rights came from the Childhood Policies Project. This was a four year programme (1992 - 1995) "directly inspired" by the adoption of the CRC. ${ }^{91}$ The importance of the opportunity to express views by the child and his or her participation in decision-making processes was one of the leading principles this project was based on.

Several rights of the child are guaranteed by the European Social Charter (Revised). ${ }^{92}$ The provisions of the Convention for the Protection of Human Rights and Fundamental Freedoms (the ECHR) can also give rise to participation of children. ${ }^{93}$ The applicability of the ECHR provisions to children makes it possible to address complaints alleging violations of children's participatory rights to the European Court of Human Rights. The decisions of this Court regarding children's participation are rare. It was, however, reaffirmed by the European Commission of Human Rights in the admissibility decision regarding the application by Irka Cederberg-Lappalainen vs. Sweden that children fully enjoy the right freedom of

\footnotetext{
89 Malcolm D. Evans and Rachel Murray, eds., The African Charter on Human and People's Rights: the System in Practice, 1986-2000 (Cambridge: The Press Syndicate of the University of Cambridge, 2005), p. 15.

${ }_{90}$ European Convention on the Adoption of Children, Opened for signature in Strasbourg, April 24, 1967, ETS No. 58; European Convention on the Legal Status of Children Born out of Wedlock, Opened for signature in Strasbourg, October 15, 1975, ETS No. 85; European Convention on Recognition and Enforcement of Decisions concerning Custody of Children and on Restoration of Custody of Children, Opened for signature in Luxemburg, May 20, 1980, ETS No. 105; European Convention on the Exercise of Children's Rights, Opened for signature in Strasbourg, January 25, 1996, Entered into force 1 July 2000, ETS No. 160.

${ }^{91}$ The Rights of the Child. A European Perspective (Council of Europe, 1996), p. 5.

92 Such as the protection before birth through rights for pregnant women (Articles 8, 11); rights of the family (Articles 16, 27, 31); legal status of the child (Article 17); rights of children in conflict with the law (Article 17); right to health (Article 11); protection from violence, abuse and sexual exploitation, protection for children without parental care (Articles 17, 7); right to education (Articles 10, 15, 17); prohibition of child labour (Articles 7, 1); working conditions for children aged 15-18 (Article 7); rights of migrant children (Article 19).

93 These are articles: 9 - Freedom of thought, conscience and religion; 10 - Freedom of expression; 11 Freedom of assembly and association (Convention for the Protection of Human Rights and Fundamental Freedoms, 4 November, 1950, ETS No. 005; reproduced at the official web-page of the Council of Europe: http://conventions.coe.int). Article 2 of the Protocol 1 to the Convention for the Protection of Human Rights and Fundamental Freedoms, dealing with the right to education, can also be referred to (Protocol 1 to the Convention for the Protection of Human Rights and Fundamental Freedoms, Entered into force on November 1, 1998, ETS No. 155; reproduced at the official web-page of the Council of Europe: http://conventions.coe.int).
} 
expression and to assembly and association. ${ }^{94}$ The applicant alleged that the organization of a peace demonstration with the participation of children from the nursery school ${ }^{95}$ upon the condition of getting consent from parents for such participation violated the right of her and her child under articles 8, 9, 10 and 11 of the Convention and Article 2 of Protocol No. $1 .^{96}$ The responsibility to inform the parents and obtain their views on the matter was placed upon each individual preschool. The applicant was informed that public authorities had sent out the relevant instructions to the nursery schools. However, the applicant was never asked by her child's nursery school whether she supports the idea of her child's participation in that demonstration. The applicant stayed at home with her child, taking a holiday from work. With this she implied that she abstains from the demonstration. The Commission found the application manifestly ill-founded. It reasoned that the applicant's decision to keep her child at home and thereby avoiding his participation in the peace demonstration does not necessarily imply any views as to peace issues in general. Admitting that the applicant's attitude could be interpreted as a disagreement with the local authorities as to the appropriateness of arranging a peace demonstration in which children should take part, the Commission did not find that the decision concerning the organization of the demonstration can for this reason be considered to interfere with the applicant's, or her child's, rights.

Specific norms regarding children's participatory rights are centered in the European Convention on the Exercise of Children's Rights. ${ }^{97}$ References to participatory issues are found already from the preamble of this convention, according to which the member states of the CoE recognize the best interests of a child to be promoted and that due weight should be given to the views of children. Opportunity for children to participate "in proceedings affecting them before a judicial authority" is one of the objects of the convention (article 1, para. 2). According to the explanatory report to this instrument, the internal law decides whether the child is formally represented or formally participates in the proceedings. It is stated in the report that "wherever possible, views of children

\footnotetext{
94 European Commission of Human Rights of Human Rights, Irka Cederberg-Lappalainen vs. Sweden, supra note 1.

${ }_{95}$ Which was a special pre-school and leisure home activity municipal institution.

96 The major allegations concerned a violation of the child's right to respect for its integrity by the use of pre-school children in a demonstration; violation of the parents' right to respect for their private and family life, to freedom of thought and conscience and to freedom of expression by request for permission from the parents; violation of the right to freedom of peaceful assembly by the action of the authorities as the applicant submitted that "freedom" must include the right to abstain from acting. The applicant also complains that the parent is forced to disclose his/her opinion regarding an issue which has been the subject of substantial political debate. She furthermore complained that the authorities have failed to respect the right of the parents to ensure such education as is in conformity with their own religious and philosophical convictions.

97 European Convention on the Exercise of Children's Rights, supra note 90.
} 
should be presented" (para. 14).$^{98}$ This is contrast to the interpretation given by the CRC Committee, according to which "wherever possible, the child must be given the opportunity to be directly heard in any proceedings". ${ }^{99}$

The right to be informed and to express views in proceedings, guaranteed by article 3, implies the following:

A child considered by internal law as having sufficient understanding, in the case of proceedings before a judicial authority affecting him or her, shall be granted, and shall be entitled to request, the following rights:

a) to receive all relevant information;

b) to be consulted and express his or her views;

c) to be informed of the possible consequences of compliance with these views and the possible consequences of any decision.

This article has much in common with article 12 of the CRC. Firstly, a requirement of "having sufficient understanding" is close to the requirement of a child "capable of forming his or her own" opinion, fixed by the CRC. The reference to the provisions of domestic law to determine the rules, according to which the child can participate in the proceedings, is also common for both instruments. At the same time, the analyzed article of this European convention limits the applications of children participatory rights only by judicial proceedings. Article 12 of the CRC refers to administrative proceedings as well.

The control mechanism of this convention is be exercised through the Standing Committee on the European Convention on the Exercise of Children's Rights. The Standing Committee should evaluate the application of the Convention and propose measures to improve its operation (article 18). The Standing Committee should report its findings to the Committee of Ministers. The Committee held its first meeting in 2006 where it adopted the rules of procedure. The next meeting of the Committee was to be held in 2009. ${ }^{100}$ It has not yet been held. Thus, there is no praxis of this Committee available.

Nevertheless, participation of children remains in the focus of various institutions within the Council of Europe. The issues of children's participation in matters affecting them are clarified in resolutions and recommendations of the

\footnotetext{
${ }^{98}$ European Convention on the Exercise of Children's Rights, Explanatory Report, European Treaty Series No. 160; reproduced at the website of the Council of Europe: http://conventions.coe.int/treaty/en/Reports/Html/160.htm.

${ }^{99}$ UN Committee in the Rights of the Child, General Comment 12, supra note 3, para. 35.

${ }^{100}$ Report of the 1st meeting (Strasbourg, 8-9 June 2006), Strasbourg, November 8, 2006, T-ED (2006), RAP 3 E rev [T-ED/2006/docs/ Meeting report revised]; reproduced at the website of the Council of Europe:

http://www.coe.int/t/dghl/standardsetting/family/T-ED\%20Meeting\%20report\%20TED\%20_2006_\%203\%20e\%20Rev.pdf.
} 
Committee of Ministers. ${ }^{101}$ Specific programmes enhancing minor's civic participation are run under the aegis of the CoE. For example, the programme "Building a Europe for and with Children" was launched by the Committee of Ministers. It was prolonged for three years as the Strategy on the Rights of the Child 2009-2011 (Stockholm Strategy) was adopted. ${ }^{102}$ Children's participation and their influence in society is one of five strategic objectives of the Strategy, which provides, among other things, that the Council of Europe should "promote children's access to information concerning their rights and human rights education for children; promote awareness raising on the right of the child to participate in decision-making processes and facilitate exchange of experience and good practices". ${ }^{103}$ The activities of the Congress of Local and Regional Authorities of Europe are also noteworthy. With regards to the enhancement of children's participation, the congress issues recommendations on how to improve the situation around the minors' participatory rights. ${ }^{104}$

\section{CONCLUSIONS}

The practical implementation of children's participatory rights as they are stipulated by the CRC is confronted by a wide variety of problems at the national level. The analysis of the reporting materials of the CRC Committee has revealed

${ }^{101}$ In Resolution (77) 33 (Resolution (77) 33 on the placement of children, Adopted by the Committee of Ministers on November 3, 1977, at the 277th meeting of the Ministers' Deputies; reproduced at the website of the Council of Europe:

https://wcd.coe.int/wcd/com.instranet.InstraServlet?command=com.instranet.CmdBlobGet\&InstranetIm age $=595111 \&$ SecMode $=1 \&$ DocId $=659764 \&$ Usage $=2$ ), the Committee recommended governments to encourage the participation of children in the management of their placement and to give them the opportunity to discuss their situation progressively as they mature in understanding (para 2.4). Principle 7 of Recommendation No R (87) 6 on foster families, adopted by the Committee of Ministers on 20 March 1987, at the 405th meeting of the Ministers' Deputies, provides that, before a decision is taken by the competent authority concerning the grant of certain parental responsibilities to foster parents, "the child should be consulted if his degree of maturity with regard to the decision so permits" (Recommendation No R (84) 4 of the Committee of Ministers of the Council of Europe on parental responsibilities, Adopted by the Committee of Ministers on February 28, 1984, at the 367th meeting of the Ministers' Deputies; reproduced at the website of the Council of Europe:

http://www.coe.int/t/DGHL/STANDARDSETTING/FAMILY/Rec.84.4.\%20E.pdf) contains such a principle of parental responsibilities: "when the competent authority is required to take a decision relating to the attribution or exercise of parental responsibilities and affecting the essential interests of the children, the latter should be consulted if their degree of maturity with regard to the decision so permits" (principle 3).

${ }_{102}$ The strategy flyer in English is available at the website of the Council of Europe:

http://www.coe.int/t/transversalprojects/children/pdf/StrategyProgramme_en.pdf.

103 Promoting the participation by children in decisions affecting them. Parliamentary Assembly Recommendation 1864 (2008), Council of Europe, Reply adopted by the Committee of Ministers on November 4, 2009, at the 1069th meeting of the Ministers' Deputies, CM/AS(2009)Rec1864 final 6 November 2009; reproduced at the website of the Council of Europe:

https://wcd.coe.int/wcd/ViewDoc.jsp?id=1534073\&Site=CM. This document has been classified restricted at the date of issue; it will be declassified in accordance with Resolution Res(2001)6 on access to Council of Europe documents.

104 See, for example, the Revised European Charter on the Participation of Young People in Local and Regional Life mentions "participation in social life" regarding young people (article 12) (Revised European Charter on the Participation of Young People in Local and Regional Life, Charter without the status of a convention, Adopted by the Congress of Local and Regional Authorities of Europe (10th session - May 21, 2003 - Appendix to the Recommendation 128); reproduced at the website of the Council of Europe: http://www.coe.int/t/dg4/youth/coe_youth/Youth_Participation_Charter_en.asp). 
that the role of a child as an active participant in family, school, and other social institutions is as a rule not denied. Exceptions still happen in the states in which traditional culture-based attitudes prevent children from such participation. However, the matters affecting children refer in one way or another to political issues. This is among the reasons why the CRC Committee "urges states parties to move from an events based approach to the right to participation to the systematic inclusion of children in policy matters" ${ }^{105}$. The importance of this issue has never lost its topicality since the adoption of the CRC Convention. As has been demonstrated in this article the CRC Committee has constantly returned to the question of children's participation in its General Comments. This still holds true. General Comment 11 dealing with the rights of indigenous children under the convention draws specific attention to the forms in which these children may participate in all matters affecting them. ${ }^{106}$ The focus of the last adopted General Comment 12 fully is concentrated fully on the expression of children's views.

Having considered regional treaty regulation concerning limited participatory rights of children, it is possible to observe that, as a main rule, it generally meets the standards of the CRC. Member states of regional organizations either recognize the provisions of the CRC as the corpus juris for children's rights (the OAS) or adopt their own participatory regulation of the rights of the child compatible with the universal regulation (the $\mathrm{AU}$ ). Some member states undertake a mixed approach, combining the previous two solutions (COE).

As an overall observation, the scope of minors' participatory rights is the widest at the level of the Council of Europe. Legal regulation of children's participatory rights at the level of other regional organizations is rather limited in its scope, if at all exists. The recent introduction and therefore the emerging phase of their regional treaty-monitoring bodies do not let making any authoritative conclusions as for the realization of regional treaty provisions regarding children's rights. The relevant information from the NGO reports and the research literature allows the tentative conclusion that serious human rights problems and traditional practices at the level of, for example, the LAS and the African Union prevent children's participation from being among the first and primary goals. However, the mere introduction of regional treaty norms concerning children's rights, albeit at the beginning a normative façade, is proof of gradual changes in national legal systems under the influence of the universal standards.

105 The Right of the Child to be Heard (2006), UN Committee on the Rights of the Child, Days of Discussion, Recommendations, UN Doc. CRC/C/43/3 (2007), para. 1008; reproduced at the website "Bayefsky": http://www.bayefsky.com.

${ }^{106}$ Indigenous Children and their Rights under the Convention, UN Committee on the Rights of the Child, Fiftieth Session, General Comment No. 11 (2009), February 12, 2009, UN Doc. CRC/C/GC/11, paras. 20, 31, 39, 57, 63; reproduced at the website "Bayefsky"// http://www.bayefsky.com. 


\section{BIBLIOGRAPHY}

1. Atwood, Barbara. "The Voice of the Indian Child Strengthening the Indian Child Welfare Act through Children's Participation." Arizona Law Review 50 (2008): 127 - 156.

2. Barber, Benjamin. Strong Democracy: Participatory Politics for a New Age. Berkeley: University of California Press, 1990.

3. Biakotozky, Noah. "Overcoming Collective Action Failure in the Security Council: would Direct Regional Representation better Protect Universal Human Rights?" Buffalo Human Rights Law Review 15 (2009): 1 - 41.

4. Birnbaum, Rachel, and Nicholas Bala. "Judicial Interviews with Children in Custody and Access Cases: Comparing Experiences in Ontario and Ohio." International Journal of Law, Policy and the Family 24 (2010): 300 - 331.

5. Donnelly, Mary and Ursula Kilkelly. "Child-Friendly Healthcare: Delivering on the Right to be Heard." Medical Law Review 19 (2011): 27 - 54.

6. Evans, Malcolm D., and Rachel Murray, eds. The African Charter on Human and People's Rights: the System in Practice, 1986-2000. Cambridge: The Press Syndicate of the University of Cambridge, 2005.

7. Gamble, John King, Teresa A.Bailey, Jared S. Hawk, and Erin E. McCurdy. "Human Rights Treaties: a Suggested Typology, an Historical Perspective." Buffalo Human Rights Law Review 7 (2001): 33 - 54.

8. Graham, Lorie M. "A Right to Media?" Columbia Human Rights Law Review 41 (2010): $429-507$.

9. Habermas, Jurgen. Legitimation Crisis. Cambridge: Polity Press, 1989.

10. Hay, Kathryn. "A Pacific Human Rights Mechanism: Specific Challenges and Requirements." Victoria University of Wellington Law Review 40 (2009): 195 214.

11. Langlaude, Sylvie. "On how to Build a Positive Understanding of the Child's Right to Freedom of Expression." Human Rights Law Review 10 (2010): 33 66.

12. Le Blanc, Lawrence J. The Convention on the Rights of the Child. Lincoln: University of Nebraska Press, 1995.

13. Muscroft, Sara, ed. Children's Rights: Reality or Rhetoric? The UN Convention on the Rights of the Child: the First Ten Years. London: the International Save the Children Alliance, 1999.

14. Parker, Mary Caroline. "'Other Treaties': the Inter-American Court of Human Rights Defines its Advisory Jurisdiction." American University Law Review 33 (1983): $211-246$. 
15. Reisman, W. Michael. "Practical Matters for Consideration in the Establishment of a Regional Human Rights Mechanism: Lessons from the Inter-American Experience." Saint Louis-Warsaw Transatlantic Law Journal (1995): 89 - 101.

16. The Rights of the Child. A European Perspective. Council of Europe, 1996.

17. Rishmawi, Mervat. "The Arab Charter on Human Rights and the League of Arab States: the Update." Human Rights Law Review 10 (2010): 169 - 178.

18. Rutherford, Jane. "One Child, One Vote: Proxies for Parents." Minnesota Law Review 2 (1998): 1463 - 1524.

19. Tyler, Tom R., and Darley, John M. "Building a Law-Abiding Society: Taking Public Views about Morality and the Legitimacy of Legal Authorities into Account when Formulating Substantive Law." Hofstra Law Review 28 (2000): 707-739.

20. Verhellen, Eugeen. Convention on the Rights of the Child: Background, Motivation, Strategies, Main Themes. Antwerp-Apeldoorn: Garant, 2000.

\section{LEGAL REFERENCES}

1. African Charter on Democracy, Election and Governance. African Union. Adopted by the Eighth Ordinary Session of the Assembly, held in Addis Ababa, Ethiopia, January 30, 2007 [according to the information given in the official web-page of the African Union, the Charter is no yet in force] // http://www.africa-union.org/root/au/Documents/Treaties/treaties.htm.

2. American Convention on Human Rights. OAS Treaty Series No. 36, 1144 UNTS 123 [entered into force July 18, 1978; reprinted in Basic Documents Pertaining to Human Rights in the Inter-American System, OEA/Ser.L.V/II. 82 doc. 6 rev.1 at 25 (1992); reproduced at the website of the University of Minnesota Human Rights Library:

http://www1.umn.edu/humanrts/oasinstr/zoas3con.htm].

3. American Declaration of the Rights and Duties of Man. O.A.S. Res. XXX. Adopted by the Ninth International Conference of American States (1948) [reprinted in Basic Documents Pertaining to Human Rights in the InterAmerican System, OEA/Ser.L.V/II.82 doc. 6 rev.1 at 17 (1992)].

4. Arab Charter on Human Rights. Council of the League of Arab States. Adopted on September 15, 1994 [not in force; reprinted in 18 Hum. Rts. L.J. 151 (1997)].

5. Arab Charter on Human Rights. League of Arab States. Adopted on May 22, 2004 [reprinted in 12 Int'l Hum. Rts. Rep. 893 (2005); entered into force March 15, 2008]. 
6. Challenges to Human Security in the Arab Countries. Arab Human Development Report 2009. United Nations Development Programme [reproduced at the website of UNPD, Arab Human Development Reports:

http://www.arab-hdr.org/contents/index.aspx?rid=5].

7. Concluding Observations on Algeria. UN Doc. CRC A/53/41 (1998).

8. Concluding Observations on Antigua and Barbuda. UN Doc. CRC/C/15/Add.247.

9. Concluding Observations on Bahrain. Un Doc. CRC CRC/C/114 (2002).

10. Concluding Observations on Belgium. UN Doc. CRC A/51/41 (1996).

11. Concluding Observations on Benin. UN Committee on the Rights of the Child. UN Doc. CRC/C/BEN/CO/2).

12. Concluding Observations on Chad. UN Doc. CRC C/87 (1999).

13. Concluding Observations on Costa Rica. UN Doc. CRC/C/15/Add.266.

14. Concluding Observations on Dominican Republic. UN Doc. CRC CRC/C/103 (2001).

15. Concluding Observations on Egypt. UN Doc. CRC A/49/41 (1994).

16. Concluding Observations on Fiji. UN Doc. CRC/C/79 (1998).

17. Concluding Observations on Finland. UN Doc. CRC A/51/41 (1996).

18. Concluding Observations on Grenada. UN Doc. CRC CRC/C/94 (2000).

19. Concluding Observations on Guinea. UN Doc. CRC CRC/C/84 (1999).

20. Concluding Observations on Honduras. UN Doc. CRC A/51/41 (1996).

21. Concluding Observations on Iceland. Un Doc. CRC A/51/41 (1996).

22. Concluding Observations on India. UN Doc. CRC/C/15/Add.228.

23. Concluding Observations on Iran (Islamic Republic of). UN Doc. CRC CRC/C/97 (2000).

24. Concluding Observations on Ireland. UN Doc. CRC A/53/41 (1998).

25. Concluding Observations on Jordan. UN Doc. CRC/C/JOR/CO/3.

26. Concluding Observations on Kazakhstan. UN Doc. CRC/C/KAZ/CO/3.

27. Concluding Observations on Kenya. UN Doc. CRC/C/KEN/CO/2.

28. Concluding Observations on Kuwait. UN Doc. CRC CRC/C/80 (1998).

29. Concluding Observations on Lao People's Democratic Republic. UN Doc. CRC A/53/41 (1998).

30. Concluding Observations on Lesotho. UN Doc. CRC/C/103 (2001).

31. Concluding Observations on Malawi. UN Doc. CRC CRC/C/114 (2002).

32. Concluding Observations on Malaysia. UN Doc. CRC/C/MYS/CO/1.

33. Concluding Observations on Maldives. UN Doc. CRC/C/MDV/CO/3.

34. Concluding Observations on Mongolia. UN Doc. CRC A/51/41 (1996).

35. Concluding Observations on Niger. UN Doc. CRC CRC/C/118 (2002). 
36. Concluding Observations on Nigeria. UN Doc. CRC/C/15/Add.257.

37. Concluding Observations on the Islamic Republic of Iran. UN Doc. CRC/C/15/Add.254.

38. Concluding Observations on Vanuatu. UN Doc. CRC CRC/C/90 (1999).

39. Concluding Observations on Yemen. UN Doc. CRC A/51/41 (1996).

40. Convention for the Protection of Human Rights and Fundamental Freedoms. November 4, 1950, ETS No. 005 [reproduced at the official web-page of the Council of Europe: http://conventions.coe.int].

41. Convention on the Rights of Child. September 2, 1990, 1577 UNTS 3 [reproduced at the web-page of the Office of the UN Commissioner for Human Rights: http://www2.ohchr.org/english/law/crc.htm].

42. European Convention on Recognition and Enforcement of Decisions concerning Custody of Children and on Restoration of Custody of Children. Opened for signature in Luxemburg, May20, 1980. European Treaty Series No. 105.

43. European Convention on the Adoption of Children. Opened for signature in Strasbourg, April 24, 1967. European Treaty Series No. 58.

44. European Convention on the Exercise of Children's Rights. Opened for signature in Strasbourg, January 25, 1996. European Treaty Series No. 160.

45. European Convention on the Exercise of Children's Rights. Explanatory Report. European Treaty Series No. 160.

46. European Convention on the Legal Status of Children Born out of Wedlock. Opened for signature in Strasbourg, October 15, 1975. European Treaty Series No. 85.

47. Forced Evictions, and the Right to Adequate Housing. UN Committee on Economic, Social and Cultural Rights. General Comment No. 7 (Sixteenth session, 1997). UN Doc. E/1998/22, annex IV at 113 (1997) [reprinted in Compilation of General Comments and General Recommendations Adopted by Human Rights Treaty Bodies, UN Doc. HRI/GEN/1/Rev.6 at 45 (2003)].

48. General Measures of Implementation of the Convention on the Rights of the Child (arts. 4, 42 and 44, para. 6). UN Committee on the Rights of the Child. General Comment No. 5, November 27, 2003, UN Doc. CRC/GC/2003/5.

49. Indigenous Children and their Rights under the Convention. UN Committee on the Rights of the Child, Fiftieth Session. General Comment No. 11 (2009), February 12, 2009, UN Doc. CRC/C/GC/11.

50. Initial Report of Andorra. UN Committee on the Rights of the Child. July 3, 2001, UN Doc. CRC/C/61/Add.3.

51. Initial Report of Austria. UN Committee on the Rights of the Child. June 26, 1997, UN Doc. CRC/C/11/Add.14. 
52. Initial Report of Iran (Islamic Republic of). UN Committee on the Rights of the Child. July 23, 1998, UN Doc. CRC/C/41/Add.5 (1997).

53. Initial Report of Mali. UN Committee on the Rights of the Child, Addendum. September 8, 1997, UN Doc. CRC/C/3/Add.53.

54. Initial Report of South Africa. UN Committee on the Rights of the Child. May 22, 1999, UN Doc. CRC/C/51/Add.2.

55. Irka Cederberg-Lappalainen vs. Sweden. European Commission of Human Rights of Human Rights, Appl. No. 11356/85 (1987) [inadmissible].

56. Juridical Condition and Human Rights of the Child. Inter-American Court of Human Rights, Advisory Opinion OC-17/2002, August 28, 2002 [requested by the Inter-American Commission on Human Rights, Inter-Am. Ct. H.R. (Ser. A) No. 17 (2002)].

57. On the Entry into force of the Arab Charter on Human Rights. Statement by UN High Commissioner for Human Rights // http://www.unhchr.ch/huricane/huricane.nsf/view01/6C211162E43235FAC12 573E00056E19D?opendocument.

58. 'Other Treaties' Subject to the Consultative Jurisdiction of the Court (Art. 64, American Convention on Human Rights). Inter-American Court of Human Rights, Advisory Opinion No. OC 2 /82 (1982). Inter-Am. Ct. of Human Rights, Sept. 24, 1982 [reprinted in 3 HUM. RTS. L.J. 140 (1982); reproduced at the official web-page of the Inter-American Court of Human Rights: http://www.corteidh.or.cr/opiniones.cfm].

59. Promoting the participation by children in decisions affecting them. Parliamentary Assembly Recommendation 1864 (2008). Council of Europe. Reply adopted by the Committee of Ministers on November 4, 2009, at the $1069^{\text {th }}$ meeting of the Ministers' Deputies. CM/AS(2009)Rec1864 final November 6, 2009 [reproduced at the web-page of the Council of Europe: https://wcd.coe.int/wcd/ViewDoc.jsp?id=1534073\&Site=CM].

60. Protocol 1 to the Convention for the Protection of Human Rights and Fundamental Freedoms. Entered into force on November 1, 1998. ETS No. 155 [reproduced at the official web-page of the Council of Europe: http://conventions.coe.int].

61. Recommendation No R (84) 4 of the Committee of Ministers of the Council of Europe on parental responsibilities. Adopted by the Committee of Ministers on February 28, 1984, at the $367^{\text {th }}$ meeting of the Ministers' Deputies [reproduced at the website of the Council of Europe: http://www.coe.int/t/DGHL/STANDARDSETTING/FAMILY/Rec.84.4.\%20E.pdf]. 
62. Report. The African Committee of Experts on the Rights and Welfare of the Child. Eighth Meeting, Addis Ababa, Ethiopia, November 27 -December 1, 2006 [reproduced at:

http://www.africaunion.org/root/au/Conferences/Past/2006/November/SA/child/Provisional_Ag enda.doc].

63. Report of the 1st meeting (Strasbourg, 8-9 June 2006). Strasbourg, November 8, 2006, T-ED (2006), RAP 3 E rev [T-ED/2006/docs/ Meeting report revised; reproduced at the website of the Council of Europe: http://www.coe.int/t/dghl/standardsetting/family/TED\%20Meeting\%20report\%20T-ED\%20_2006_\%203\%20e\%20Rev.pdf].

64. Resolution (77) 33 on the placement of children. Adopted by the Committee of Ministers on November 3,1977 , at the $277^{\text {th }}$ meeting of the Ministers' Deputies [reproduced at the website of the Council of Europe: https://wcd.coe.int/wcd/com.instranet. InstraServlet?command=com. instranet .CmdBlobGet\&InstranetImage $=595111 \&$ SecMode $=1 \&$ DocId $=659764 \&$ Usage $=$ 2].

65. Revised European Charter on the Participation of Young People in Local and Regional Life. Charter without the status of a convention. Adopted by the Congress of Local and Regional Authorities of Europe ( $10^{\text {th }}$ session - May 21, 2003 - Appendix to the Recommendation 128) [reproduced at the website of the Council of Europe:

http://www.coe.int/t/dg4/youth/coe_youth/Youth_Participation_Charter_en.a $\mathrm{sp}]$.

66. Second Periodic Report of Austria. UN Committee on the Rights of the Child. July 8, 2004, UN Doc. CRC/C/83/Add.8.

67. Second Periodic Report of Canada. UN Committee on the Rights of the Child. March 12, 2003, UN Doc. CRC/C/83/Add.6.

68. Second Periodic Report of Chad. UN Committee on the Rights of the Child. December 14, 2007, UN Doc. CRC/C/TCD/2*.

69. Stop Child Executions! Ending the Death Penalty for Child Offenders. Amnesty International, Report (September 15, 2004). ACT 50/015/2004.

70. The African Charter of the Rights and Welfare of a Child. Organization of African Unity. Entered into force November 29, 1999. OAU Doc. CAB/LEG/24.9/49 (1990).

71. The Right of the Child to be Heard (2006). UN Committee on the Rights of the Child. Days of Discussion. Recommendations, UN Doc. CRC/C/43/3 (2007). 
72. The Right of the Child to Be Heard. UN Committee on the Rights of the Child, Fifty-First Session. General Comment No. 12 (2009), UN Doc. CRC/C/GC/12.

73. The Right of the Child to Protection from Corporal Punishment and other Cruel or Degrading Forms of Punishment (arts. 19; 28, para. 2; and 37, inter alia). UN Committee on the Rights of the Child, Forty-Second Session. General Comment No. 8 (2006), UN Doc. CRC/C/GC/8.

74. The Right to the Highest Attainable Standard of Health. UN Committee on Economic, Social and Cultural Rights. General Comment No. 14 (Twentysecond session, 2000), UN Doc. E/C.12/2000/4 (2000) [reprinted in Compilation of General Comments and General Recommendations Adopted by Human Rights Treaty Bodies, UN Doc. HRI/GEN/1/Rev.6 at 85 (2003)].

75. Third and Fourth Periodic Reports of the United Kingdom of Great Britain and Northern Ireland. UN Committee on the Rights of the Child. February 25, 2008, UN Doc. CRC/C/GBR/4, the Isle of Man. 